\title{
Alternative Fuels for Spark Ignition Engines
}

\author{
Yousef S.H. Najjar ${ }^{*}$ \\ Mechanical Engineering Department, Jordan University of Science and Technology, Irbid, Jordan
}

\begin{abstract}
In order to reduce the atmospheric pollution emitted by automobiles, control devices are being incorporated in the vehicles in many countries. This has resulted in a reduced vehicle mileage to the extent of about fifteen percent. Without the introduction of new technology, any further reduction in emission levels would be expected to extract payment in the form of further fuel economy losses. It is, therefore, worthwhile to look into the suitability of "clean" burning fuels for use in internal combustion engines and assess their potential for reducing engine exhaust emissions. So the investigation of alternative fuels becomes very necessary.

In this work three types of fuels are investigated: Alcoholic fuels, gaseous fuels and liquid fuels.

Their properties were inserted in a computer program which was specially designed to calculate the performance of a spark ignition engine over wide range of operating conditions (design and off-design). The design operating variable namely compression ratio, advance angle, engine speed and spark advance were chosen for each fuel based on the physical and chemical properties and the resulting fuel-engine interactions such as mixing, flammability and knock. The resulting performance includes power, specific fuel consumption and thermal efficiency. Their variation with equivalence ratio, engine speed and spark advance was calculated and plotted in the figures and briefly mentioned in the conclusions.

The engine variables including temperature, pressure and volume were calculated at different points of the cycle. Hence the P-V and the P-rc diagrams were drawn for the different alternative fuels. These diagrams are considered unique contribution to the characterization of alternative fuels.
\end{abstract}

\section{INTRODUCTION}

The increased use of automobiles and the rapid rate of industrial development in the world made petroleum supplies unable to keep up with demands. Moreover, petroleum fuels pollute the environment with their combustion products. Control devices were used to reduce pollution, but resulted in about $15 \%$ reduction in the vehicle mileage [1]. It is, therefore, worthwhile to look into the suitability of using "clean" burning fuels for use in spark ignition engines (S.I.E).

Using of alternative fuels maybe achieved by converting an existing engine to operate on either the original fuel and the alternative fuel "dual fueling" or, in general, a specially designed engine for the new fuel will offer better performance [2].

Two categories of fuels are investigated: alcoholic fuels and gaseous fuels. Alcohols could be produced from renewable resources and produce less exhaust pollutants. Gaseous fuels offer, cleaner combustion due to improved fuel-air mixture preparation and higher $\mathrm{H} / \mathrm{C}$ ration than in conventional liquid fuels [2].

In this work the effect of different fuels on engine performance was studied using specially designed Fortran computer program for gasoline. The predicted results compared favorably with the actual engine performance at the same

*Address correspondence to this author at the Mechanical Engineering Department, Jordan University of Science and Technology, Irbid, Jordan; Tel: 00962785793463; Fax: 0096227100836;

E-mail:y_najjar@hotmail.com operating conditions. Hence, the program was further extended and modified for the other fuels.

\section{ANALYSIS}

\section{A. Effects of Fuel on Engine and Vehicle Performance and Technology}

\section{Methanol and Ethanol}

Methanol and ethanol have a number of similar properties and hence require similar attention when considering fueling, combustion, storage and handling [2].

Alcohols have high oxygen content hence lower stoichiometric air-fuel ratio. Consequently engine displacement volume Vd could be reduced. However, alcohols have approximately half the internal energy of combustion (Urp) of that of gasoline.

Thereby to obtain the same power output from the engine, the flow rate of alcohol needs to be doubled and consequently the relevant air, thus keeping $\mathrm{Vd}$ unaltered, but increasing the capacity of carburetor jets, injectors, fuel pumps and tanks.

Methanol has a latent heat of vaporization $\mathrm{h}_{\mathrm{fg}}$ about four times that of gasoline. This coupled to the fact that twice the fuel quantity to be used, means that the heat required for vaporization is about eight times greater for methanol. In S.I.E. this heat must be supplied in the inlet manifold prior to entry into engine cylinders, to avoid sever wear problems within the engine.

However, correct vaporization results in decrease of inlet air temperature resulting in improved volumetric efficiency 
and greater torque and power. Reduction in vehicles' gear ratios should be made to take advantage of the increase in torque, if fuel economy is to be improved. High $\mathrm{h}_{\mathrm{fg}}$ and oxygen content may contribute to poor driveability.

The relatively high fixed boiling point of alcohols results in low vapour pressure not sufficient to start the engine, resulting in poor cold starting performance. This can be overcome with the use of heaters, more volatile fuel additive or employing a secondary "cold start" fuel.

Being a polar fluid, methanol may be incompatible with many metals and elastomers [3]. It is more corrosive than ethanol. Metals affected, such as $\mathrm{Mg}, \mathrm{Al}, \mathrm{Zn}$ and $\mathrm{Cu}$ should be replaced or plated with nickel for protection. The exposure of plastic and rubber components- in the fuel delivery system - to alcohol can cause swelling and softening. Hence, proper material selection is essential. Other engine and vehicle modifications include: spark plugs with higher heat rating; suitable engine oil; corrosion resistant and increased capacity fuel tank and lines; and modified bearings.

Taking advantage of the higher octane rating, the compression ratio can be increased to 12 without encountering spark knock, which results in higher thermal efficiency and power output for the same energy input as petrol. This coupled with the ability to burn lean mixtures with improved volumetric efficiency and soot free combustion means that alcohols are viable alternative to gasoline in spark ignition engines [2].

The addition of ethanol (10\%) to gasoline in S. I. E. with a typical 3-way catalyst increases both Research Octane Number (RON) and the Reid vapour pressure but increases emissions of acetaldehyde and ethanol; whereas addition of methyl tertiary butyl ether (MTBE) causes only an increase in RON with less unburned HC, CO and acetaldehyde [4].

The addition of ethanol to diesel in compression ignition engine results in $\mathrm{CO}$ reduction due to presence of more oxygen in the combustion process. However, the power decreases with the increase of ethanol [5].

\section{Gaseous Fuels}

Engines fueled with gaseous fuels have certain advantages over gasoline-fueled engines, such as:

a- Less scale and gum build-up inside the combustion chamber, thus requiring less frequent engine overhaul.

b- Eliminating most of the starting difficulties associated with gasoline.

c- $\quad$ Proper distribution of fuel-air mixture over the cylinders, thereby reducing the cyclic variation problem.

d- Reduced evaporative emission from carburetor and fuel tank, whereas with gasoline it is a major factor that affects air pollution.

e- Reduced contamination of lubricating oil, thereby extending periods between oil and filter changes.

f- Less pollutants with less corrosive elements improves the service life of the exhaust system.

The main gaseous fuels considered in this work are: natural gas, hydrogen and synthetic fuels. Gases could be ob- tained from chemical industry with low thermal value of $0.54 \mathrm{kWh} / \mathrm{Nm}^{3}$; gases with low methane numbers (e.g. high $\mathrm{H}_{2}$ content) and hence low knock resistance; and gases with very high thermal value up to $34 \mathrm{kWh} / \mathrm{Nm}^{3}$ (butane) [6].

\section{Natural Gas (NG)}

It consists mainly of about $95 \%$ methane, $3 \%$ ethane with smaller percentage of propane and butane.

Natural gas can be used as an automotive fuel either compressed in cylinders $\mathrm{CNG}$ or liquefied LNG. In practice $\mathrm{LNG}$ is rarely used as it is more expensive and difficult to handle. Due to its high octane number O.N., higher compression ratio $r_{c}$ could be used to benefit from the 33\% higher combustion rate, hence $\mathrm{NG}$ is an excellent fuel for spark ignition engines [4].

Emissions from a NG vehicle are $80 \%$ reduced (compared to gasoline) especially $\mathrm{CO}$ and $\mathrm{NO}_{\mathrm{X}}[1]$, thereby dispensing with three-way catalyst needed by S.I. engines. However, refueling systems require a compressor which increases the cost to $\$ 2000-\$ 4000$ per vehicle.

The relative disadvantages associated with using the NG is the reduction in the engine volumetric efficiency. Moreover, NG must be stored in a high pressure tank which is heavy and reduces the payload and luggage space. An NG car with 75 litre tank is about $150 \mathrm{~kg}$ heavier than its gasoline counterpart [8].

Small changes in the concentration of butane produce linear significant changes in both the values of knock limited compression ratio for fixed spark timing and the knocklimited spark timing for a fixed compression ratio [9].

The use of syngas with NG extends the exhaust gas recirculation (EGR) tolerance by $45 \%$ on mass basis compared to $\mathrm{NG}$ only, leading to $77 \%$ reduction in $\mathrm{NO}_{\mathrm{X}}$ over $\mathrm{NG}$ with EGR [10].

Considering thermal stability and heat transfer, it was found that the use of high-purity methane instead of N.G. at temperature, above $775 \mathrm{~K}$, could reduce the deposit thickness by as much as a factor of three, or permit operation at correspondingly higher temperatures [11].

\section{Hydrogen}

Hydrogen can be considered as a true alternative fuel as it can be derived by electrolysis from non-fossil fuel source, namely water. However, hydrogen could be added to the gasoline-air mixture in the intake system, thereby extending the lean equivalence ratio $\Phi$ for smooth operation from 0.8 to 0.5 , making the mixture easier to burn and reducing the pumping work at part load thereby improving mechanical efficiency [9]. Lean hydrogen mixture assists with fuel economy and in reducing unburned fuel and $\mathrm{NO}_{\mathrm{X}}$ as exhaust emission.

Furthermore, hydrogen offers many advantages for the improvement of the combustion process. This is due to some favorable combustion properties such as: wide flammability limits, low ignition energy in air, high flame speed and high heating value. The high flame speed and wide flammability limits are of particular interest gasoline and methane have significant disadvantages with respect to these two proper- 
ties. Therefore, it can be expected that the addition of hydrogen to these two fuels would improve combustion [12].

In spite of these advantages, hydrogen has some problems such as: abnormal combustion in the form of preignition, back firming and spark knock due to low ignition energy. Storage is a major difficulty where an expensive and heavy tank in the vehicle is needed to contain hydrogen compressed or liquefied [13]. A disadvantage of hydrogen fuel in the S.I. engine is the reduction of the engine's volumetric efficiency; hence the maximum power from the same engine will go down by about $20 \%$ with hydrogen.

\section{Synthetic Fuels}

Due to the huge reserves of coal in many countries, it has been hardly tried to utilize it in engines in different ways. However, due to its high sulphur content, the removal of $\mathrm{SO}_{2}$ from the resulting stack gases is an expensive process. Thus considerable efforts have been directed toward the development of processes for converting coal to clean fuels, both gaseous and liquid.

Gasification processes have been developed which could produce synthetic fuel with approximate formula $\left(\mathrm{CH}_{2} \mathrm{O}\right)_{\mathrm{n}}$. A typical volumetric analysis of the fuel is: $0.3 \% \mathrm{CH}_{4}, 29.6 \%$ $\mathrm{H}_{2}, 41 \% \mathrm{CO}, 10 \% \mathrm{CO}_{2}, 17 \% \mathrm{H}_{2} \mathrm{O}$ and $0.8 \% \mathrm{~N}_{2}$. Hence, $\mathrm{CH}_{4}$ and $\mathrm{N}_{2}$ can be neglected, $\mathrm{H}_{2} \mathrm{O}$ can be removed by using vapour trap and $\mathrm{CO}_{2}$ extracted for other uses. This results in a fuel which consists of $\mathrm{CO}$ and $\mathrm{H}_{2}$. Advanced gasifiers are being developed which produce $\mathrm{H}_{2}$ and $\mathrm{CO}$ in roughly equal amounts [15].

Although synthetic fuel-air mixtures are slower burning than gasoline-air mixtures, the first should be used with low compression ratio $r_{c}$ engine to avoid knock. However, it was found that with synthetic fuels the engine $r_{c}$ can be increased to 14 instead of 8 the typical value for gasoline [3]. This is thought to be due to the relatively lower heating value, hence lower heat release per unit mixture with consequent reduced temperature and lower tendency to knock.

Biodiesel is being recently developed to be used as a fuel in compression ignition engines CIE [16, 17]. The combustion related properties of vegetable oils are some what similar to diesel oil. Neat vegetable oils or their blends with diesel, however pose various long-term problems in C.I.E. e.g.: poor atomization characteristics, ring sticking, injector coking, injector deposits, injector pump failure and lube oil dilution by crank-case polymerization. These undesirable features of vegetable oils are due to their inherent properties like high viscosity, low volatility and polyunsaturated character [16]. Using $20 \%$ biodiesel-fuelled engine, the physical wear of various vital parts, injector coking, carbon deposits on piston and ring sticking were found to be substantially lower. The lube oil analysis showed lower wear and thus improved life for biodiesel operated engines [16, 17].

\section{B. Fuel Performance in Internal Combustion Engines}

It is essential to explore the fuel performance relative to different engine designs. This covers a range of parameters that are fundamental to basic vehicle operation and those related to engine performance. These parameters and their relationship to key fuel properties are discussed below [12]:
Fuel handling and delivery to the injection point into the engine is related to fuel properties such as viscosity, cloud point, pour point and vapour pressure.

Initiation of combustion is related to spontaneous ignition temperature Tsp, vapour pressure, viscosity, volatility, stoichiometric F/A ratio (F/A)st and flame speed [18] combustion stability is affected by laminar flame speed $\mathrm{S}_{\mathrm{L}}$, flammability limits, viscosity and Tsp.

Materials compatibility is associated with the ability of fuel-wetted metallic and elastomeric materials to withstand corrosion and dimensional instability. Key fuel properties are sulfur content, acidity and aromatic content.

Wear life of fuel pump, fuel system and injectors is related to lubricant and particulate content. High -temperature corrosion of combustion chamber, igniter and injectors are related to vanadium, $\mathrm{Ni}, \mathrm{K}, \mathrm{S}$ and $\mathrm{Na}$ contents. Ceramics are less sensitive to these contaminants.

Low-temperature corrosion due to contact with cool exhaust gases is related to sulfur content.

Exhaust emissions are affected by the percent content of aromatics, carbon, sulfur, particulate, nitrogen, hydrogen, oxygen and ash. Other properties are (F/A)st and maximum flame temperature.

Power output is related to $(\mathrm{A} / \mathrm{F}) \mathrm{st}$, internal energy of combustion Urp, and maximum flame temperature:

Fuel consumption depends on engine thermal efficiency, power and F/A besides Urp.

Reliability and durability is affected by ash and particulates, gum content, metals content, lubricity, fuel stability and carbon residue.

Safety in fuel tank and engine, to avoid fire when the engine is shut down, is affected by flammability limits, vapour pressure, flash point, Tsp and electrical conductivity.

\section{DISCUSSION OF RESULTS}

\section{Alternative Fuels-Engine Relationship}

A computer program initiated by Campell using $\mathrm{C}_{8} \mathrm{H}_{18}$ as fuel [19], was utilized then further modified to compare the performance of spark ignition engine S.I.E., using gasoline taking into consideration the four following modifications on the fuel air cycle, namely : progressive combustion, valve timing, heat transfer and friction [19]. The operating variables namely $r_{c}$, SA and rpm were varied as shown in Table $\mathbf{1}$ with gasoline, whereas the corresponding experimental results are shown in Table 2. The experimental device was a single cylinder variable compression engine with

$\mathrm{B}=0.095 \mathrm{~m}, \mathrm{~S}=0.082 \mathrm{~m}, \mathrm{~L}=0.155 \mathrm{~m}, \mathrm{AO}=7.068 \mathrm{~mm}^{2}$

$\mathrm{IVO}=36^{\circ} \mathrm{ABDC}, \mathrm{EVO}=36^{\circ} \mathrm{BBDC}, \mathrm{VDISP}=0.58123 \times 10^{-3} \mathrm{~m}^{3}$

The average operating conditions were assumed

$\mathrm{PM}=\mathrm{P}_{1}=101.4 \mathrm{k} \mathrm{Pa}$

$\mathrm{Tg}=1500 \mathrm{~K}$

$\mathrm{Tw}=400 \mathrm{~K}$

$\mathrm{R}=8.314 \mathrm{~kJ} / \mathrm{kmol} \mathrm{K}$ 
Table 1. Operating Variables with Gasoline D.P

\begin{tabular}{|c|c|c|c|c|}
\hline CR & 6.00 & 7.00 & 8.00 & 10.00 \\
\hline SA & 0.00 & 5.00 & 10.0 & 20.00 \\
\hline $\mathbf{r p m}$ & 1250 & 1500 & 2000 & 2250 \\
\hline
\end{tabular}

Table 2. Experimental Results for Different Speeds with Gasoline

\begin{tabular}{|c|c|c|c|c|}
\hline Engine Speed (rpm) & 1250 & 1500 & 2000 & 2250 \\
\hline Power $(\mathbf{k W})$ & 5.3 & 6.8 & 8.7 & 8.4 \\
\hline s.f.c. $(\mathbf{g} / \mathbf{k W h})$ & 374.4 & 323 & 306 & 381 \\
\hline
\end{tabular}

The detailed predicted results for different modifications along with the experimental results are shown in Table 3. The comparison is favorable with average variation of $(4.6 \%)$ in power and $(-2.87 \%)$ in sfc. gives the overall picture of operation and performance at the design point for the different fuels.

The following figures show the off-design performance of the engine. Fig. (1) shows the variation of brake power $\mathrm{P}_{\mathrm{b}}$ with equivalence ratio $\Phi$, for different fuels. All the fuels manifest maximum $\mathrm{P}_{\mathrm{b}}$ at stoichiometric fuel air mixture $\Phi=1$ consistent with maximum temperature.

Fig. (2) shows minimum brake specific fuel consumption bsfc around the stoichiometric $\Phi$ where maximum temperature results in maximum combustion rate hence heat release rate which is directly related to fuel consumption.

Fig. (3) shows the maximum brake thermal efficiency $\eta$ at stoichiometric $\Phi$, consistent with the reverse relation between bsfc and $y$.

An important operating parameter is the engine speed $\mathrm{N}$. Fig. (4) shows the variation of $\mathrm{P}_{\mathrm{b}}$ with $\mathrm{N}$. It increases steadily until $2500 \mathrm{rpm}$ is reached for all fuels. Methanol $\mathrm{CH}_{3} \mathrm{OH}$ produces the highest $\mathrm{P}_{\mathrm{b}}$ for the same heat input, whereas

Table 3. Power and sfc at Different rpm for Different Modifications at Design Point

\begin{tabular}{|c|c|c|c|c|c|c|c|c|c|c|c|c|}
\hline \multicolumn{2}{|c|}{ Experimental } & \multicolumn{2}{|c|}{ Friction } & \multicolumn{2}{c|}{ Heat Transfer } & \multicolumn{2}{c|}{ Valve Timing } & \multicolumn{2}{c|}{ Prog. Combustion } & \multicolumn{2}{c|}{ Ideal } & \multirow{2}{*}{ Modification } \\
\hline s.f.c & Power & s.f.c & Power & s.f.c & Power & s.f.c & Power & s.f.c & Power & s.f.c & Power & rpm \\
\hline \hline 374.40 & 5.30 & 400.2 & 5.04 & 348.53 & 5.79 & 325.18 & 6.20 & 288.98 & 6.98 & 250.25 & 8.06 & 1250 \\
\hline 323.00 & 6.80 & 331.10 & 6.65 & 289.76 & 7.60 & 269.50 & 8.20 & 244.098 & 9.02 & 220.88 & 9.97 & 1500 \\
\hline 306.00 & 8.70 & 297.20 & 9.10 & 257.02 & 10.52 & 239.88 & 11.3 & 211.08 & 12.24 & 199.4 & 13.54 & 2000 \\
\hline 381.00 & 8.40 & 348.8 & 9.22 & 294.52 & 10.92 & 275.2 & 11.7 & 256.49 & 12.55 & 218.09 & 14.55 & 2250 \\
\hline
\end{tabular}

Table 4. Operating Particulars of the Different Fuels

\begin{tabular}{|c|c|c|c|c|c|c|c|c|c|}
\hline Property & Com. R & RON & $\phi_{\text {mis fire }}$ & $\phi_{\mathbf{p l}}$ & $\phi_{\mathbf{f l}}$ & $\left(\mathbf{O}_{2} / \mathbf{F}\right) \mathbf{s}$ & $\mathbf{H . V}, \mathbf{M J} / \mathbf{k g}$ & $\mathbf{M M}, \mathbf{k g} / \mathbf{k m o l}$ & $\mathbf{r}_{\mathbf{c}}$ \\
\hline \hline $\mathrm{C}_{7.12} \mathrm{H}_{14.56}$ & - & 95 & 0.8 & 0.9 & 1.2 & 10.76 & 43.7 & 100 \\
\hline $\mathrm{C} \mathrm{H}_{3} \mathrm{O} \mathrm{H}$ & Higher & 105 & & 0.8 & 1.3 & 1.5 & 20 & 32 \\
\hline $\mathrm{C}_{1.1} \mathrm{H}_{4.2}$ & Higher & 120 & 0.5 & 0.6 & 1.1 & 2.15 & 50 & 12 \\
\hline $\mathrm{C}_{0.58} \mathrm{H}_{0.84} \mathrm{O}_{0.58}$ & Lower & - & 0.5 & - & 1.1 & 0.5 & 15.5 & 17 \\
\hline $2 \% \mathrm{H}_{2}+$ Gasoline & Higher & 98 & 0.5 & 0.7 & 1.3 & 11.04 & 49.68 & 100 \\
\hline
\end{tabular}

This success in using the modified model to predict performance with gasoline, encouraged its use with other fuels which are considered as candidate alternative fuels for the S.I.E., such as methanol $\mathrm{CH}_{3} \mathrm{OH}$, natural gas $\mathrm{NG}$, synthetic gas from coal, and mixture of gasoline and hydrogen. The operating particulars of these fuels along with gasoline are shown in Table 4. Thus, further modifications in the modified computer program are carried out to take these particulars into consideration.

In addition to the basic three operating variables namely $\mathrm{N}, \Phi$ and SA which were used with gasoline, the compression ratio $r_{c}$ is now added to represent the effect of fuel on knock requirements of the engine. Table $\mathbf{5}$ shows the values of these variables at the design point with six fuels. Table 6 natural gas and the synthetic fuel gives the lowest power due to the drop of volumetric efficiency.

Fig. (5) shows the maximum $y$ at $1500 \mathrm{rpm}$, a condition of part load but relatively low friction power.

Table 5. Design Points for the Fuels

\begin{tabular}{|c|c|c|c|c|c|c|}
\hline Fuel & $\begin{array}{c}\text { Iso- } \\
\text { Octane }\end{array}$ & Gasoline & Methanol & CNG & Syn. Fuel & H2 + Gasoline \\
\hline \hline CR & 9 & 9 & 12 & 14 & 14 & 9 \\
\hline rpm & 2500 & 2500 & 2500 & 2500 & 2500 & 2500 \\
\hline$\phi$ & 1.2 & 1.2 & 1.3 & 1.1 & 1.1 & 1.3 \\
\hline SA & 20 & 20 & 20 & 15 & 20 & 20 \\
\hline
\end{tabular}


Table 6. Operating Variables and Results of Different Fuels at Design Point

\begin{tabular}{|c|c|c|c|c|c|c|}
\hline Fuel & C8H18 & C7.12H14.56 & CH3OH & C1.1H4.2 & C.58H.84O.58 & Gasol. + H2 \\
\hline \hline$\Phi$ & 1.2 & 1.2 & 1.3 & 1.1 & 1.1 & 1.3 \\
\hline $\mathrm{N}(\mathrm{rpm})$ & 2500 & 2500 & 2500 & 2500 & 2500 & 2500 \\
\hline $\mathrm{SA}^{\circ}$ & 20 & 20 & 20 & 15 & 20 & 20 \\
\hline Brake Power $(\mathrm{kW})$ & 12.31 & 12.16 & 15.42 & 11.08 & 11.10 & 12.5 \\
\hline Torque (N.m) & 48.40 & 47.75 & 60.85 & 42.32 & 42.40 & 51.22 \\
\hline BSFC (g/kWh) & 302.59 & 311.08 & 575.39 & 254.03 & 811.96 & 335.78 \\
\hline$\eta \%$ & 26.61 & 26.48 & 26.88 & 30.33 & 28.60 & 23.70 \\
\hline
\end{tabular}

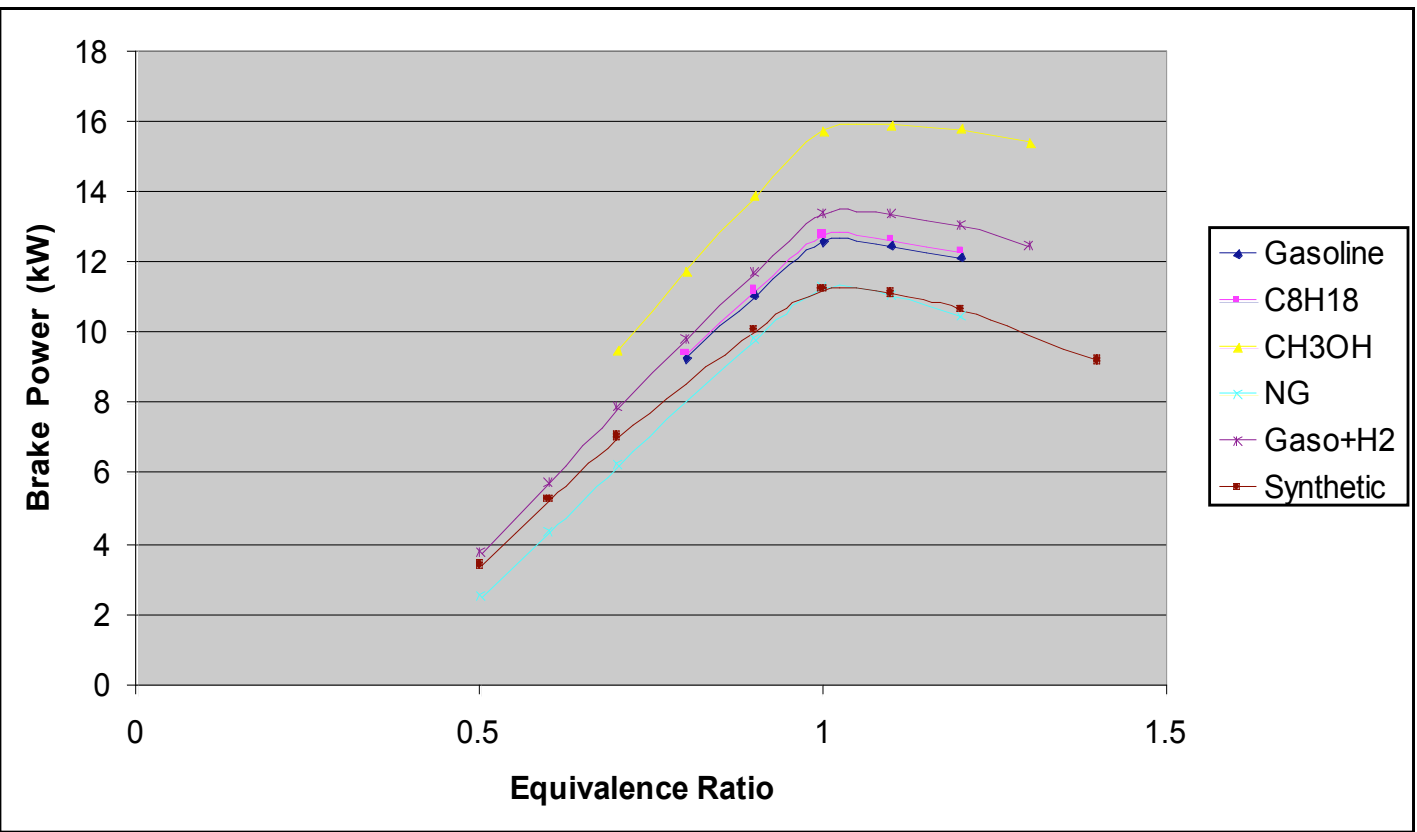

Fig. (1). Variation of brake power with equivalence ratio for different fuels.

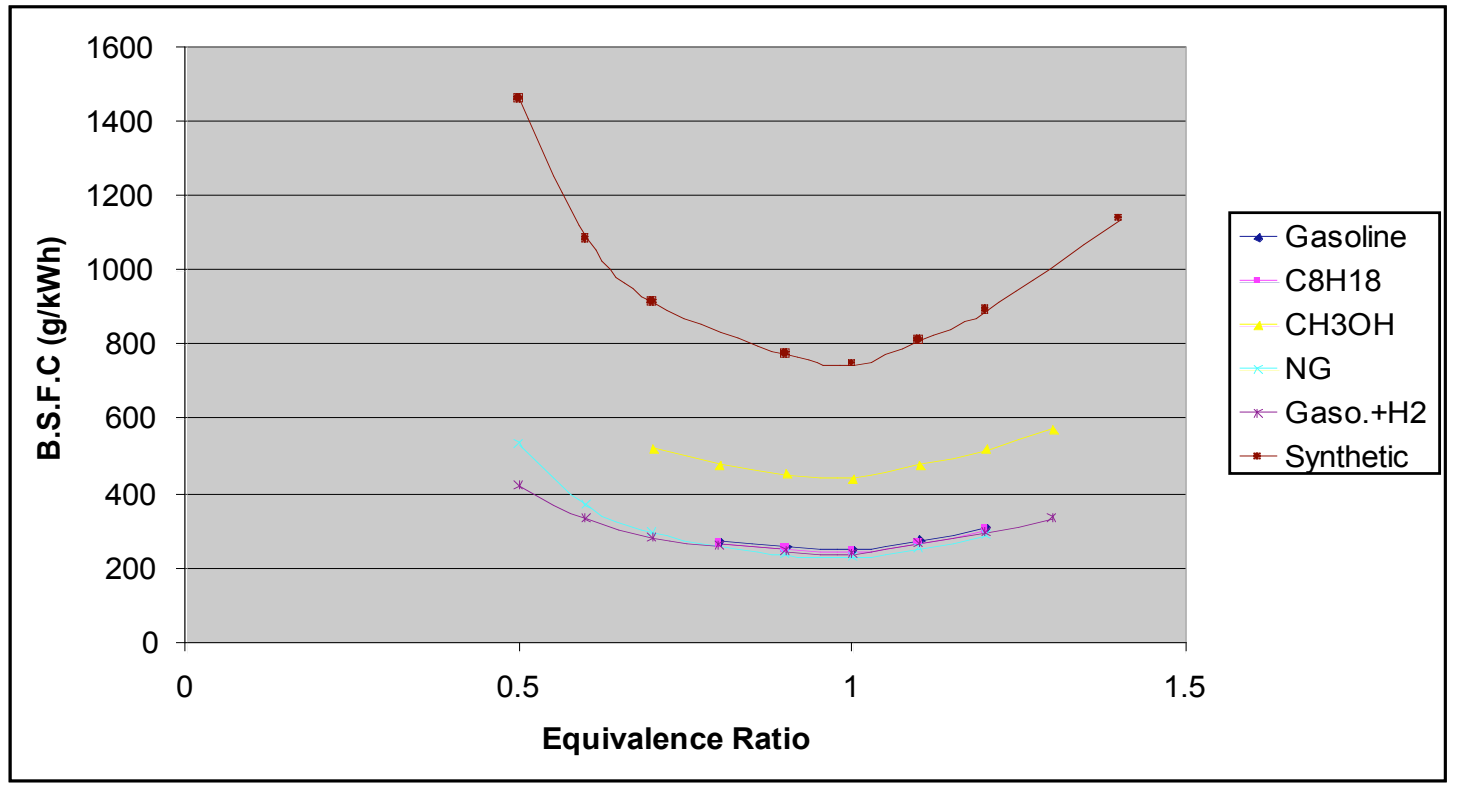

Fig. (2). Variation of brake specific fuel consumption with equivalence ratio for different fuels. 


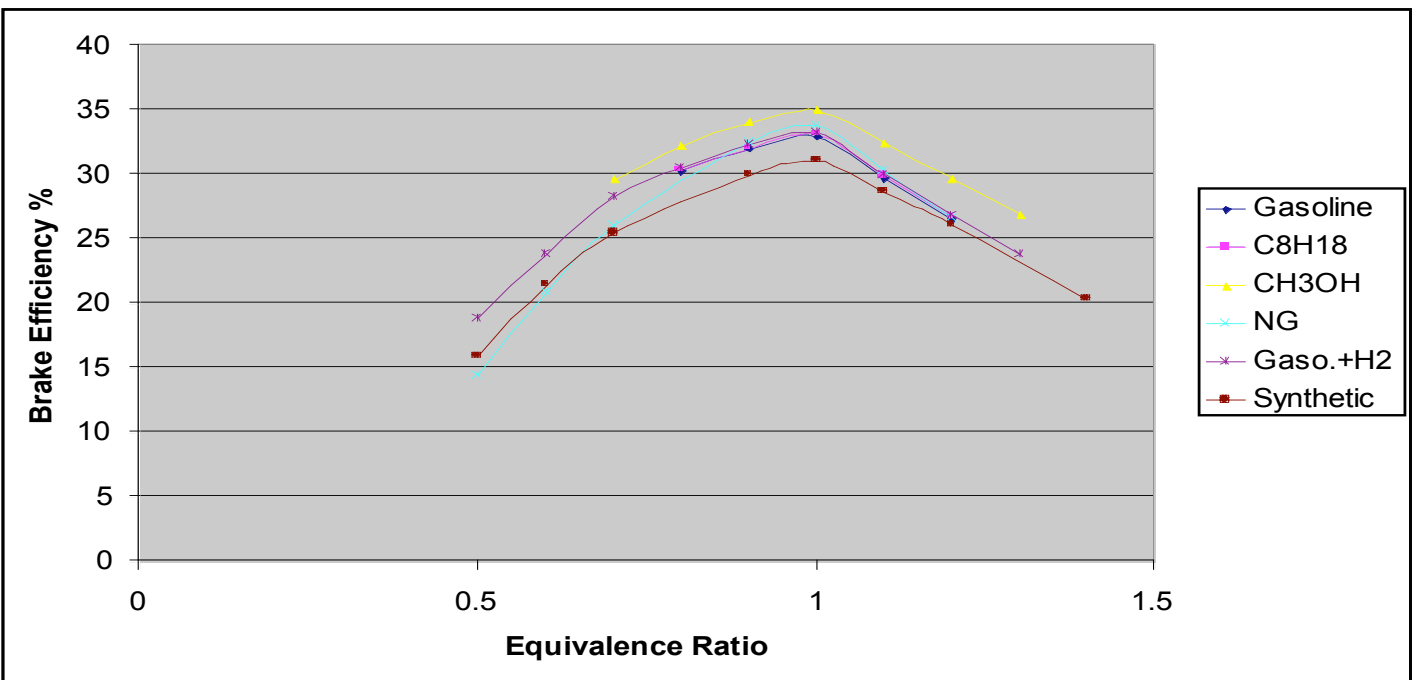

Fig. (3). Variation of brake efficiency with equivalence ratio for different fuels.

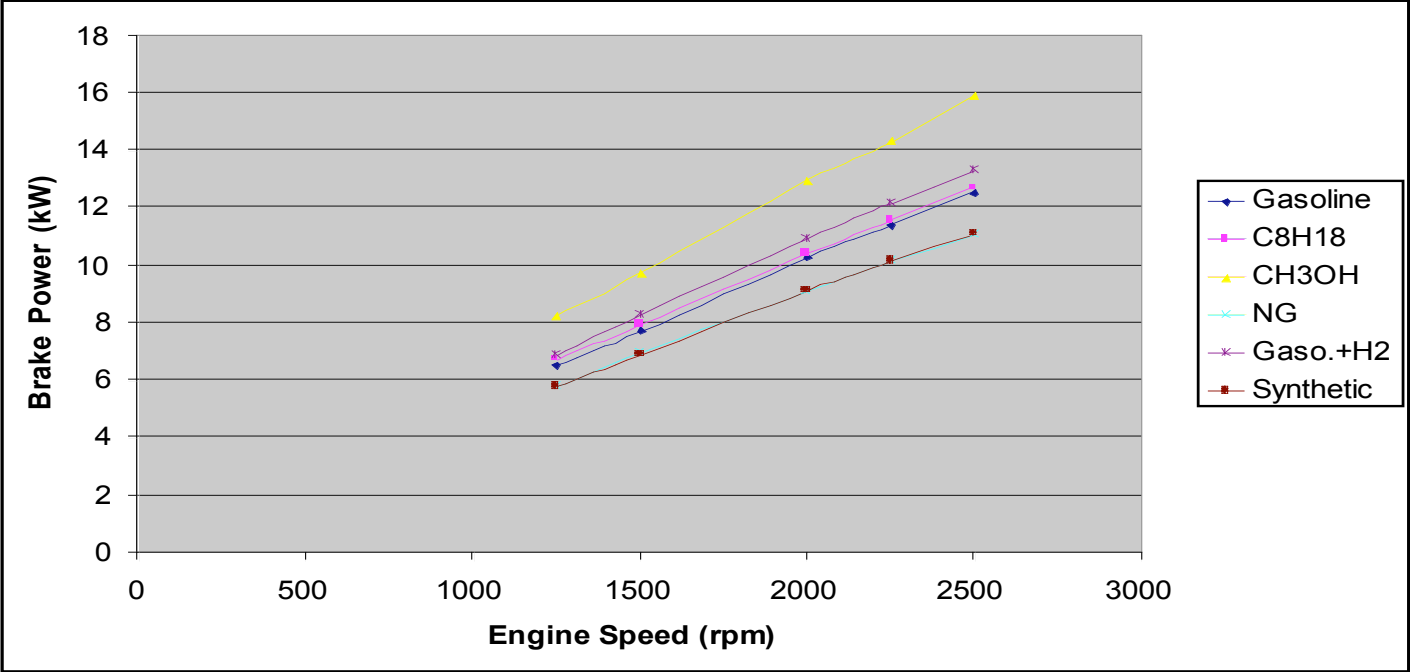

Fig. (4). Variation of brake power with engine speed for different fuels.

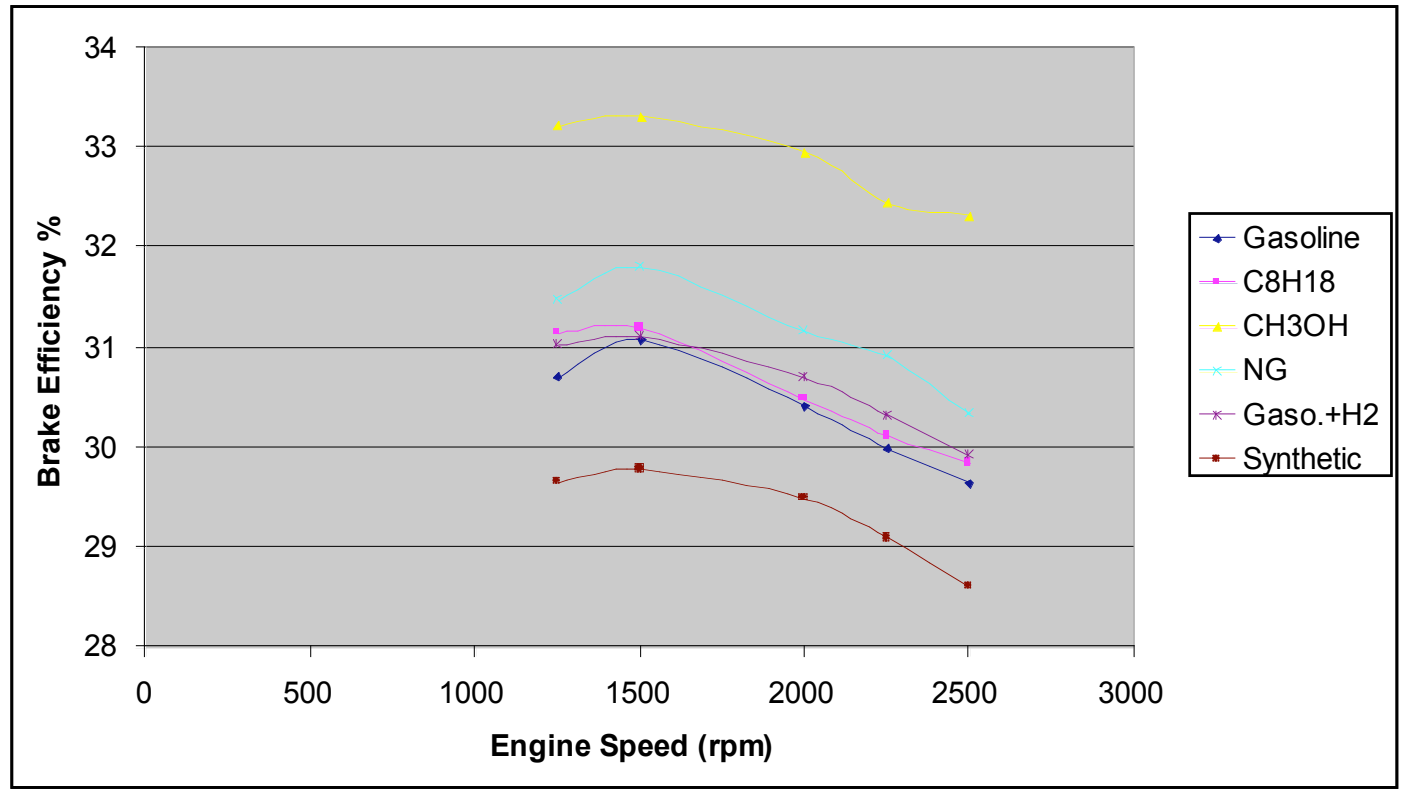

Fig. (5). Variation of brake efficiency with engine speed for different fuels. 
Table 7 shows the resulting values of pressure, volume and temperature at the different points of the cycle for all the fuels. Hence, it becomes possible to draw Fig (6) which shows a nice comparison of the different fuels on the P-V diagram at their design points. However, they are not very different at BDC due to using the same engine for all the fuels.

Therefore, Fig. (7) was drawn to show the P-rc diagrams for the different fuels which have different design compression ratio depending on fuel properties. Now the differences are more obvious at BDC.

\section{CONCLUSIONS}

1. Iso-octane produces more brake power than gasoline by $1.2 \%$, It shows an increase in brake thermal efficiency $\eta$ by $0.5 \%$ and reduction in brake specific fuel consumption bsfc by $2.7 \%$, which means that they are almost equivalent.

2. For the same energy input, Methanol produces more brake power than gasoline by $21 \%$, It shows an increase in $\eta$ by $11 \%$ and an increase in bsfc by $46 \%$.
3. Natural gas produces less brake power than gasoline by $10 \%$, It shows an increase in $\eta$ by $13 \%$ and reduction in bsfc by $18 \%$.

4. Gasoline-Hydrogen mixture produces brake power more than gasoline by $7 \%$, It shows an increase in $\eta$ by $2 \%$ and reduction in bsfc by $5 \%$.

5. Synthetic fuel produces less brake power than gasoline by $12 \%$, It shows a decrease in $\eta$ by $2 \%$ and an increase in bsfc by $65 \%$.

6. Spark advance from $0-15^{\circ}$ BTDC increases the brake power by $5 \%$ and the $\eta$ by $5 \%$, and decreases bsfc by $4 \%$. Spark advance from $15-25^{\circ}$ BTDC increases the brake power by $2 \%$ and the $\eta$ by $1.5 \%$, and decreases bsfc by $1.8 \%$.

7. The ratio of brake power to the engine speed increases by $15 \%$. At low engine speed the $\eta$ increases by $2 \%$ and the bsfc decreases by $1 \%$. At high engine speed the $\eta$ decreases by $1 \%$ and the bsfc increases by $2 \%$.

Table 7. Pressure, Volume and Temperature with Different Fuels Throughout the Cycle

\begin{tabular}{|c|c|c|c|c|c|c|c|c|c|c|c|c|c|c|c|c|c|}
\hline \multicolumn{3}{|c|}{$\mathrm{C}_{8} \mathrm{H}_{18}$} & \multicolumn{3}{|c|}{$\mathrm{C}_{7.12} \mathrm{H}_{14.56}$} & \multicolumn{3}{|c|}{$\mathrm{C} \mathrm{H}_{3} \mathrm{OH}$} & \multicolumn{3}{|c|}{$\mathrm{C}_{1.1} \mathrm{H}_{4.2}$} & \multicolumn{3}{|c|}{$\mathrm{C}_{.58} \mathrm{H}_{.84} \mathrm{O}_{.58}$} & \multicolumn{3}{|c|}{ Gasoline + H2 } \\
\hline $\begin{array}{c}\mathbf{P} \\
(\mathbf{k P a})\end{array}$ & $\begin{array}{c}V^{*} 10^{3} \\
\left(m^{3}\right)\end{array}$ & $\begin{array}{c}\mathbf{T} \\
(\mathbf{K})\end{array}$ & $\begin{array}{c}P \\
(\mathrm{kPa})\end{array}$ & $\begin{array}{l}V^{*} 10^{3} \\
\left(m^{3}\right)\end{array}$ & $\begin{array}{c}\mathbf{T} \\
(\mathbf{K})\end{array}$ & $\begin{array}{c}\mathbf{P} \\
(\mathbf{k P a})\end{array}$ & $\begin{array}{l}V^{*} 10^{3} \\
\left(m^{3}\right)\end{array}$ & $\begin{array}{c}\mathbf{T} \\
(\mathbf{K})\end{array}$ & $\begin{array}{c}\mathbf{P} \\
(\mathbf{k P a})\end{array}$ & $\begin{array}{c}V^{*} 10^{3} \\
\left(m^{3}\right)\end{array}$ & $\begin{array}{c}\mathbf{T} \\
(\mathbf{K})\end{array}$ & $\begin{array}{c}\mathbf{P} \\
(\mathbf{k P a})\end{array}$ & $\begin{array}{c}V^{*} 10^{3} \\
\left(m^{3}\right)\end{array}$ & $\begin{array}{c}\mathbf{T} \\
(\mathbf{K})\end{array}$ & $\begin{array}{c}\mathbf{P} \\
(\mathrm{kPa})\end{array}$ & $\begin{array}{c}V^{*} 10^{3} \\
\left(m^{3}\right)\end{array}$ & $\begin{array}{c}T \\
(\mathbf{K})\end{array}$ \\
\hline 101.4 & 0.648 & 280 & 101.4 & 0.654 & 279 & 101.4 & 0.634 & 281 & 101.4 & 0.643 & 303 & 101.4 & 0.626 & 303 & 101.4 & 0.654 & 277 \\
\hline 1810.3 & 0.093 & 645 & 1804.6 & 0.095 & 640 & 2664.8 & 0.075 & 660 & 2013.5 & 0.088 & 731 & 3682.2 & 0.067 & 843 & 1803.7 & 0.094 & 593 \\
\hline 9150.6 & 0.071 & 2963 & 9124.4 & 0.073 & 2941 & 14087 & 0.053 & 3086 & 10574 & 0.067 & 3256 & 12877 & 0.045 & 3443 & 9490.6 & 0.073 & 2813 \\
\hline 3792.7 & 0.146 & 2484 & 3788.3 & 0.147 & 2471 & 3953.3 & 0.592 & 2405 & 3568.4 & 0.155 & 2623 & 4014.7 & 0.113 & 2712 & 3368.6 & 0.167 & 2289 \\
\hline 641.25 & 0.612 & 1735 & 636.87 & 0.613 & 1728 & 700.92 & 0.634 & 1720 & 687.12 & 0.593 & 1790 & 534.45 & 0.584 & 1865 & 657.84 & 0.615 & 1642 \\
\hline
\end{tabular}

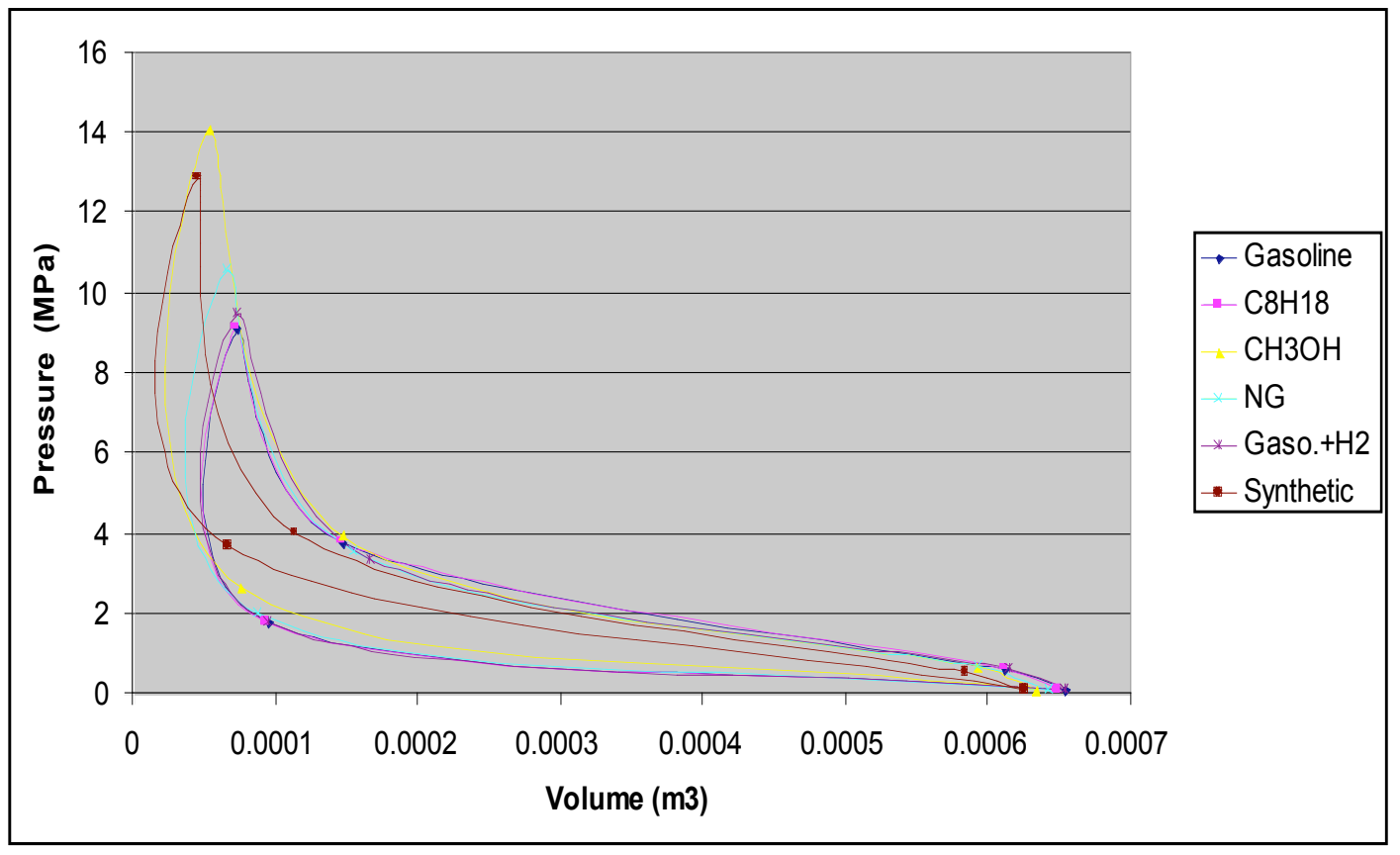

Fig. (6). Pressure volume diagram for different fuels at their design point. 


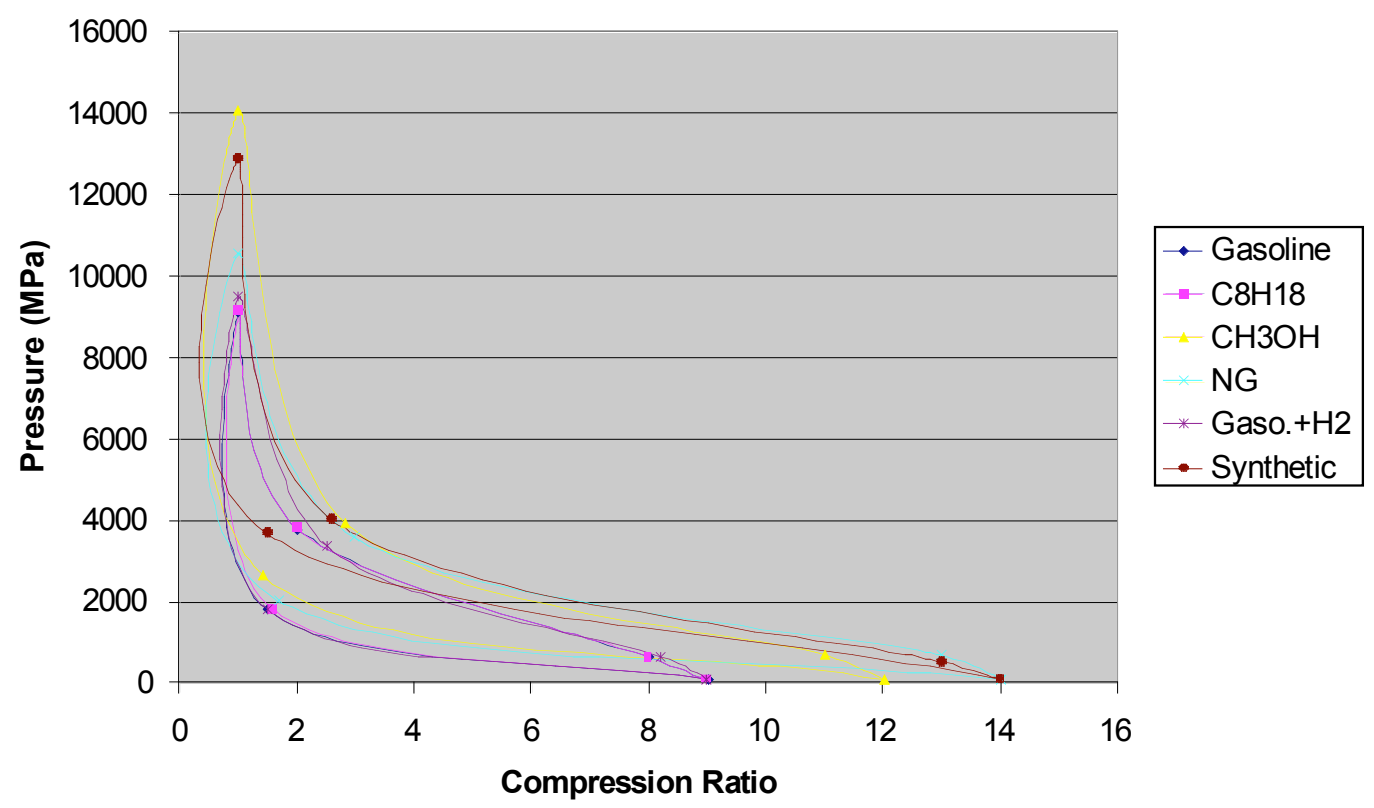

Fig. (7). Pressure vs compression ratio for different fuels.

\section{ACKNOWLEDGEMENT}

The author would like to thank engineer Mohannad AlHaddad for the help during this work.

$$
\begin{array}{ll}
\text { ABBREVIATIONS } \\
\mathrm{ABDC} & =\text { After bottom dead center degrees } \\
\mathrm{AO} & =\text { Wide open valve area for both valves } \mathrm{m} 3 \\
\mathrm{~B} & =\text { Bore } \mathrm{m} \\
\mathrm{P}_{\mathrm{b}} & =\text { Brake power } \mathrm{kW} \\
\mathrm{bsfc} & =\text { Brake specific fuel consumption } \mathrm{g} / \mathrm{kW} . \mathrm{h} \\
\mathrm{BBD} & =\text { Before bottom dead center degrees } \\
\mathrm{CIE} & =\text { Compression ignition engine } \\
\mathrm{CO} & =\text { Carbon monoxide } \\
\mathrm{EVO} & =\text { Exhaust valve open degrees } \\
\mathrm{EGR} & =\text { Exhaust gas recirculation } \\
\mathrm{F} / \mathrm{A}_{\mathrm{act}} & =\text { Actual fuel air ratio } \\
(\mathrm{F} / \mathrm{A})_{\mathrm{st}} & =\text { Stiochiometric fuel air ratio } \\
\mathrm{H} / \mathrm{C} & =\text { Hydrogen }- \text { carbon ration } \\
\mathrm{h}_{\mathrm{fg}} & =\text { Heat of vaporization } \mathrm{kJ} / \mathrm{kg} \\
\mathrm{IVO} & =\text { Inlet valve open degree } \\
\mathrm{L} & =\text { Length of the connecting rod } \mathrm{m} \\
\mathrm{N} & =\text { Engine speed rpm } \\
\mathrm{NG} & =\text { Natural gas } \\
\mathrm{p} & =\text { Pressure } \mathrm{M} \text { Pa } \\
\mathrm{RON} & =\text { Research octane number } \\
\mathrm{r}_{\mathrm{c}} & =\text { Compression ratio } \\
\mathrm{S} & =\text { Stroke } \mathrm{m}
\end{array}
$$

$\mathrm{SO}_{2} \quad=$ Sulphur dioxide

SA $=$ Spark advance degrees

SIE $=$ Spark ignition engine

$\mathrm{TM}=$ Intake manifold temperature $\mathrm{K}$

$\mathrm{T} 1=$ Temperature at the start of the compression stroke

Tsp $=$ Spontaneous ignition temperature $\mathrm{K}$

Urp = Internal energy of reaction of the fuel $\mathrm{kJ} / \mathrm{kg}$

$\mathrm{V} \quad=$ Volume $\mathrm{m}^{3}$

VBDC $=$ Volume at the bottom dead center $\mathrm{m}^{3}$

$\mathrm{Vd} \quad=$ Displacement volume $\mathrm{m}^{3}$

VTDC $=$ Clearance volume $\mathrm{m}^{3}$

\section{GREEK LETTERS}

$\begin{array}{ll}y_{\mathrm{b}} & =\text { Brake thermal efficiency } \\ \mathrm{y}_{\mathrm{v}} & =\text { Volumetric efficiency } \\ \Phi & =\text { Equivalence ratio }\end{array}$

\section{REFERENCES}

[1] La point, C. Factors affecting vehicle fuel economy. Sept, 1973 SAE Publication 730791.

[2] Green, R., and Pearce, S. Alternative transport fuels. Energy World, Oct 1994, pp 8-11.

[3] Heywood, J.B. International Combustion Engines Fundamental, McGraw-Hill Book series in mechanical engineering, New York, 1989.

[4] Poulopoulos, S.G.; Philippopolous, C.J. The effect of adding oxygenated compounds to gasoline on automotive exhaust emissions. Eng. Gas Turbine power, 2003, 125, 344-350.

[5] Arapatsakos, C.I. Testing the tractor engine using diesel-ethanol mixtures under full-load conditions. Heat Technol., 2001, 19(1).

[6] Jenbacher, JES. Utilization of special gases as energy sources. Technical Report, 2000, Austria.

[7] Greer, D. Energy alternatives to petroleum, e News Bulletin, May 2005. 
[8] Motoring and the environment. Shell Briefing Service, Number 2, 1992.

[9] Attar, A.A.; Karim, G.A. Knock rating of gaseous fuels. Transaction the ASME. Eng. Gas Turbine power, 2003, 125, 500-504.

[10] Smith, J.A.; Bartley, G.J. Stoichiometric operation of a gas engine utilizing synthesis gas and EGR for NOx control. Eng .Gas Turbine Power, 2000, 122, 617-623.

[11] Chin, D.; Hermanson, J.C.; Spadaccini, L.J. Thermal stability and heat transfer characteristics of methane and natural gas fuels. $J$. Eng. Gas Turbine Power, 1995, 117, 462-467.

[12] Rentz, R.L.; Moore, J.S.; Timbario, T.J. An investigation of issues surrounding the fuels adaptability of the advanced gas turbine. Soc Automotive Eng, Inc., 1985, 841362.

[13] Wagner, T.; Jamal, Y. Advantages of fractional addition of hydrogen to internal combustion engines by exhaust gas fuel reforming. Hypothesis Conference, April 7, 1991, 1-9.
[14] Wylen, G.J.; Sonntag, R.E. Fundam Class Thermodynamics, John Willy \& Son, New York, 1998.

[15] Stambler, I. Coproduction plant fuels GCC and makes methanol. Gas Turbine World, 1984, 28, 14-21.

[16] Agarwal, A.K.; Bijwe, J.; Das, L.M. Effect of bio-diesel utilization on wear of vital parts in compression ignition engines. J. Eng. Gas Turbine Power, 2003, 125, 604-611.

[17] Agarwal, A.K.; Das, L.M. Bio-diesel development and characterization for use as "fuel in compression ignition engines. J. Eng. Gas Turbine Power, 2001, 123, 440-447.

[18] Gokalp, I.; Lebas, E. Alternative Fuels for industrial gas turbines (AVTUR). Appl. Thermal Eng., 2004, 24, 1655-1663.

[19] Campbell, A.S. Thermodynamic analysis of combustion engine, John Wiley \& Sons, Toronto, 1980.

Received: August 19, 2008

Revised: December 12, 2008

Accepted: December 22, 2008

(C) Yousef S.H. Najjar; Licensee Bentham Open.

This is an open access article licensed under the terms of the Creative Commons Attribution Non-Commercial License (http://creativecommons.org/licenses/by$\mathrm{nc} / 3.0 /$ / which permits unrestricted, non-commercial use, distribution and reproduction in any medium, provided the work is properly cited. 